\title{
$\mathcal{T}_{\text {he }} \mathcal{J}$ ournal of $\mathcal{L}_{\text {atin }} \mathcal{A}_{\text {merican }}$ and $C$ aribiean $\mathcal{A}_{\text {nthropology }}$
}

\section{The "Black Foreigner" in the Quintana Roo Territory (Mexico): Between Otherness and Sameness}

By

Elisabeth Cunin

URMis, IRD, Université Nice Sophia Antipolis

\section{R E S U M E N}

El Territorio de Quintana Roo, en el sur-este de México, en la frontera con Belice, nace en 1902. En esta región periférica, la población constituye una herramienta estratégica de afirmación de la soberanía y de la identidad nacionales. Esta investigación propone una sociología histórica que estudia a la vez la racialización de las políticas migratorias, las medidas de integración y de desarrollo de la región y las negociaciones entre administraciones del centro (México) y de la capital del Territorio (Payo Obispo, Chetumal). Se interesa en la emergencia de una nueva entidad político-administrativa al margen de la nación y reubica México en el marco de las migraciones post-esclavistas. Se trata así de introducir una alteridad no indígena en las reflexiones sobre nación, mestizaje y raza, a partir de la figura del "extranjero negro." [extranjero, mestizaje, nación, negro, Belice, México]

\section{A B S T R A C T}

The Quintana Roo Territory in southeast Mexico on the border with Belize, was established in 1902. In this peripheral region, population plays an instrumental role with respect to strategic issues of sovereignty and national identity. Drawing on a historical sociological approach, this article examines the racialization of immigration policies, introduction of measures for integration and development of the region, and negotiations between the central government (Mexico) and the capital of Quintana Roo Territory (Payo Obispo, Chetumal). It focuses on the population politics entailed in the emergence of a new political and administrative entity at the margins of the nation and relocates Mexico at the heart of postslavery migrations. An analysis of the case of the "black foreigner," demonstrates the ways that a non-Indian "otherness" intervenes in 
concepts of and reflections on the nation, mestizaje, and race. [Belize, black, foreigner, mestizaje, Mexico, nation]

In the context of postrevolution Mexico (1910), mestizaje (race-mixing) was seen as an ideology to "make the nation," to borrow from Manuel Gamio's title (1982). Alan Knight (1990:86) demonstrates to what extent the category of "mestizo" - as a "synonym for "national race" or "mexicanness" —embodied the revolutionary regime and legitimized the nation. "Mestizaje policies" produced the mestizo as a homology of race, nationality, and citizenship. The nation was built around the "Indian problem," which was resolved through mestizaje. Postrevolution ideology was based on mixed-race nationalism, described as mestizofilia (pro-mestizaje) (Basave Benítez 2002).

This article revisits the inclusionary and exclusionary processes specific to mestizaje in postrevolution Mexico and proposes two significant shifts in general approaches to the subject: studying the place of black populations more than that of Indians, and focusing on immigrants more than on natives. It introduces a nonIndian otherness to reflect on the concepts of nation, mestizaje, and race, drawing on the case of the black foreigner who is at the same time "other" in two respects (black and foreigner) and yet not recognized as an "other" who can be integrated into the nation.

Mexican President Porfirio Díaz (1830-1915) is usually associated with an immigration policy that favored the arrival of white Europeans; however, he also contributed to the migration of black manual workers from the United States, the Caribbean, and Central America in order to develop farming, mining, railways, and forestry. Owing to its geographical location, Mexico experienced a dual migratory dynamic linked to a black postslavery diaspora at the turn of the 19th and 20th centuries: people from the United States settled or sought employment south of the border, sometimes in ambitious colonization projects; and people from the Caribbean and Central America came looking for economic opportunities.

The border between Mexico and the United States has been the subject of a number of studies, in particular on alliances between Mexican revolutionaries and black people from the south of the U.S. (Brown 1993), on attempts to establish black colonies in Mexico (de la Serna 2011; Rippy 1921; Vincent 1997), and on Afro-American migrations at the beginning of the 20th century (González Navarro 1960; Saade Granados 2009a, 2009b). There has been little research to date on Mexico's southern border, although migrations of slaves and free people between Belize and Yucatán have been recorded from the 18th century onwards (Restall 2014). 
This article explores postslavery migrations to Mexico from the Caribbean and Central America in the 19th and 20th centuries. Existing sources suggest that at the end of the 19th and beginning of the 20th century, the migration of workers from the Caribbean contributed to the economic growth of Central America, in particular in the Atlantic coast enclaves, in a context of migration laws that were either very general or widely permissive. In the years 1920-30, restrictive migration policies were adopted, which limited or prohibited the access of certain nationalities and "races" to national territories. ${ }^{1}$ This article shows that Mexico was also part of the history of the migration of black workers across the circum-Caribbean region.

The focus of this article is southeast Mexico, on the border with British Honduras (or Belize), in Quintana Roo Territory. Although both scientific studies and national narratives of Mexico associate the region with an Indian (Maya) presence, a significant number of people came to the region in the colonial era whose origins were African (Gerhard 1991), followed by migrant workers from the Caribbean and Central America. At the start of the 20th century, Porfirio Díaz encouraged the immigration of Afro-Belizean workers, some with their families, to settle in the Territory's first capital, Vigia Chico, and to help build a railway (Cunin 2014).

The Quintana Roo Territory, located on the Yucatán peninsula, was created in 1902 in order to put an end to the Caste War - a conflict between Maya Indians and the government, which had been going on since 1848. In particular, the Caste War provoked reverse migratory flows between Mexico and British Honduras: Mexicans fleeing the war sought refuge on British soil, and Belizean workers sought forestry resources in Mexico with the support of traders and the British authorities (Cal 1983; Jones 1971; Villalobos 2006). The creation of the Quintana Roo Territory also formalized the border with British Honduras, which had been established in 1893 (under the Mariscal Spencer Treaty). A central goal for the Mexican government was to integrate a noncivilized fringe and a region marked by Indian rebellions and British incursions into the nation and transform it into a symbol of Mexico (Rosado Vega 1940). The region was transformed from a "borderland" characterized by a certain degree of autonomy for native and migrant populations living on the margins of imperial/national powers, to a "border" in which shifts of population, access to land, and citizenship were decided upon by state authorities (Adelman and Aron 1999).

Quintana Roo's economic development was closely linked to forestry products-timber and chicle ${ }^{2}$ extraction-from the middle of the 19th century to the middle of the 20th century. Since the Territory was scarcely populated, it attracted foreign workers, who were mainly black migrants from neighboring Belize, as well as migrants from Central America and the Caribbean (Cunin 2014). As a territory, it had an ambivalent status, poised between having administrative 
autonomy and being under the control of the government of Mexico City. This lasted until 1974, when it became the State of Quintana Roo.

This article is based on the study of several collections of Mexican archives dated between 1924 and 1940: the National Institute of Migration's Historical Archives (Archivo Histórico del Instituto Nacional de Migración) in Mexico City, including the archives of the Migration Department, which was created in 1926; the General Agrarian Archives (Archivo General Agrario) in México City and Chetumal; and the Quintana Roo State Historical Archives (Archivo Histórico del Estado de Quintana Roo) in Chetumal. ${ }^{3}$ It draws on archives on migration patterns and agrarian archives in order to compare immigration and agrarian policies and attitudes concerning "black foreigners," which ranged from convergence to contradiction to ignorance. The article also examines documents produced in Mexico City and Chetumal in order to look at the negotiations, disagreements, and lack of understanding between the center and periphery; and it draws on administrative sources (migration, agriculture, foreign affairs, interior, economic development, customs, armed forces) in order to take account of the Mexican State's heterogeneity. The article's focus is on information about the city of Chetumal (the capital of the Quintana Roo Territory from 1915) and villages along the Río Hondo- - the river marking the border between Mexico and British Honduras (including Alvaro Obregón, Pucté, Palmar, Cocoyol, Botes, and Sabidos).

The article first explores the emergence of a "black question" in terms of race and foreignness, which was different from the integration process that eventually became linked with the Afromestizo, in particular in the work of anthropologist Gonzalo Aguirre Beltrán (1989[1946], 1974[1958]). It then looks at how the government resolved-directly and indirectly_the "black problem": the research focuses on the specific case of postrevolution Quintana Roo Territory between 1924 (which was the date of the first measure to control black immigration) and 1940 (when the Territory was officially integrated into the nation). The article also examines the racialization of immigration policies in the years 1920-30, which aimed to prohibit the entry of black immigrants into the country. The discussion encompasses the implementation of land reform in Quintana Roo and the creation of ejidos ${ }^{4}$ and cooperatives that excluded foreigners. Finally, it addresses the adoption of a postrevolution nationalist policy, which aimed to "mexicanize" the border. Between 1924 and 1935, the Mexican government excluded the "black foreigner" from the mestizo nation because the former was seen as being both incapable of being assimilated and alien. When Cárdenas became president in 1934 and Melgar was the governor, the policy of exclusion of "black foreigners" was not abandoned but was accompanied by a policy of assimilation and mexicanization. By making the black foreigner "invisible" or "the same," the government made the figure "disappear" as a problem, although black people did not disappear from the population. 


\section{“Afro-Mestizo" versus “Black Foreigner”: Inclusion and Exclusion}

The status of black populations ${ }^{5}$ was resolved by Gonzalo Aguirre Beltrán, a pioneer of black Mexican studies. He argued that the people who arrived at the time of colonization were integrated into mestizaje and into the nation; in his La población negra de México (Aguirre Beltrán 1989, first published in 1946), he concluded that differences between Afro and mestizo populations were eliminated. Afromestizo can be understood in this context: mestizaje includes Afro rather than being distinguished from it. Aguirre Beltrán's intention was to bring to light a part of Mexican society that was "forging Mexican nationality" (Aguirre Beltrán 1989: 9). Studying Afro-Mexicans gives a richer, more thorough, and more accurate understanding of mestizaje: "Every time mestizaje is mentioned in Mexico, the authors refer exclusively to the mixing of the dominant white population with the defeated American population. No one takes the trouble to consider the part played by the blacks in forging a Mexican culture" (Aguirre Beltrán 1989: 9).

A few years later (in 1958), in his ethnographic study of the village of Cuajinicuilpa (Guerrero state), Aguirre Beltrán noted that the isolated "black individuals" whom he studied were "in reality" mixed-race-the product of biological mixing and acculturation. Thus, for Aguirre Beltrán, the ethnography of black communities is a kind of ethnohistory, and African cultures and archives of the slave trade provide information on the cultural specificities of people who are now mexicanized and who, as such, are part of the dynamics of mestizaje. Aguirre Beltrán's reflection is part of indigenist ideology; his stance on black populations does not contradict the prevailing postrevolution ideology aimed at establishing a homogeneous society. ${ }^{6}$

Aguirre Beltrán's work refers to the descendants of Africans who arrived with the first Spanish settlers and throughout the slave trade era, although he mainly examines the initial phase of colonization. While Aguirre Beltrán (1989: 9) briefly mentions the recent immigration of "free workers," he does not analyze this. Although black people who arrived during the colonial period, who were largely integrated into Mexican history and society over several centuries, were of no concern to intellectuals and authorities at the beginning of the 20th century, this was not the case in relation to the more recent immigration (end of 19th century) of black settlers and workers from the United States, British Honduras, the Caribbean, and Central America. In the latter case, black people were considered as immigrant foreign workers, and seen as a threat to the homogenization process inherent to mestizaje.

Moisés González Navarro (1988) highlights a number of reactions to black immigrants at the end of the 19th century and the beginning of the 20th century, which he found in Mexican news accounts of the time, not only from journalists but also from elected representatives. Some praised black people's physical qualities 
and their capacity to adapt to tropical climates; others denounced their laziness and unruliness. Paradoxically, Mexico, which adopted very restrictive migration legislation (against black people, Chinese, Jews, etc.) between 1920 and 1930, never was a country that received high numbers of immigrants (Scott FitzGerald and Cook-Martin 2014; Yankelevich 2009).

A more thorough study of the news media at the beginning of the 20th century has yet to be carried out; nevertheless, the speech delivered by Alberto M. Carreño on April 28, 1910, in front of the Sociedad Mexicana de Geografía y Estadística (Mexican Society of Geography and Statistics), ${ }^{7}$ entitled "El peligro negro" (The Black Danger), confirmed González Navarro’s observations. A historian and writer who held numerous institutional positions of responsibility, Carreño was an influential intellectual at the beginning of the 20th century, a member of the Academia Mexicana de la Lengua (Mexican Academy of Language), president of the Sociedad Mexicana de Geografía y Estadística (Mexican Society of Geography and Statistics), and head of the Academia Mexicana de la Historia (Mexican Academy of History). He began his talk by saying that he was going to broach a "problem of thrilling interest and capital importance" — that of the immigration of "colored" people wishing to settle in Mexico. ${ }^{8}$ Backed by the neighboring examples of the United States and Cuba, he questioned the socioeconomic marginality of black populations to find out whether these were linked to historical circumstances (in particular slavery) or to their racial inferiority. His talk concluded that black people belong to an "inferior race" and that their immigration to Mexico was deemed undesirable. ${ }^{9}$

Carreño's text advanced three main concerns. First was the fear of importing a "war of races." Relations between white and black people were described as violent, conflictual, and based on a complete separation of the groups involved. Next, Mexico had enough of a challenge to resolve its "Indian problem" without "complicat [ing] matters further with the worst complication." ${ }^{10} \mathrm{He}$ went on to describe Indian people as "martyr[s] and impassive as few human being[s] can be." They would be the first victims of black people, who would reproduce against Mexican people the ill treatment they had suffered at the hands of others. Therefore, instead of lifting Indians out of their "degeneration," black people would contribute to "their being further debased and demeaned." 11 A final element, briefly mentioned, was that the financial means used to favor the immigration of black people-and foreigners more generally-should also be used for Indian people, in order to create competition between the two ethnic groups.

This text linked the "black question" to the immigration of people who were doubly "others" as black and as foreign, in a process of exogenization of otherness. If the Afromestizo was integrated into mestizaje, this was not the case with the "black foreigner," who was marked as "racially inferior" and could therefore not be assimilated. 


\section{Migration Policies: The Black Foreigner-Between Otherness and Illegality}

In the days following the 1910 Revolution, Mexico was considered to be a poor country whose natural resources were foreign-owned; furthermore, the heterogeneity of its population was regarded as an obstacle to constituting a national society. A selective, restrictive, and discretionary policy concerning foreigners entering the country was introduced via two immigration laws (in 1926 and 1930), a population law (1936), and numerous secret decrees (Cook-Martín and FitzGerald 2010; Cunin 2014; Saade Granados 2009a, 2009b; Scott FitzGerald and CookMartin 2014; Yankelevich 2009, 2011). Although Mexico was not a major receiving country of immigrants, between 1920 and 1930 it nevertheless adopted a number of measures to limit immigration, based on economic, nationalistic, and racist criteria. Thus, from 1924 onwards, specific legislation was adopted, targeting black populations, but also other population groups according to nationality, race, or religion. ${ }^{12}$

As regards Quintana Roo, on October 18, 1925, the immigration officer on duty at Payo Obispo ${ }^{13}$ issued the first refusal of entry to the country to an Englishman, David Humes, on the grounds that he was considered to belong to the "black race." 14 Other refusals followed: Florence and Ann Mc Farlin, "English citizens of Ethiopian race" who, on August 3, 1928, wanted to go to Cozumel to work as domestic employees. They were arrested in the Bay of Chetumal and sent back to Belize; ${ }^{15}$ Santiago Avila, "a well brought-up and educated Honduran of coloured race," was escorted back to the border. ${ }^{16}$ In 1929, the case of Professor Miguel Augusto Memhart aroused controversy. On June 12, Payo Obispo's immigration officer informed his superiors that he had refused Memhart entry into Mexico, "because he belongs to the black race and does not fulfil the requirements of the immigration law." 17 The following day, the Secretaría de Educación Pública sent a telegram to the Secretario de Gobernación in Payo Obispo, asking him to authorize the "black race professor," a tropical agriculture specialist, to enter the country. Nearly a month later, a telegram from Mexico's Secretaría de Gobernación ordered the Payo Obispo immigration officer to allow Memhart to enter the country and to exempt him from paying the immigration fee. ${ }^{18}$

This example highlights an essential feature of immigration policies in Quintana Roo: continuous negotiations were held between the central government and the periphery, but also between the different departments concerned, in order to interpret, apply, and justify exclusion measures. These exchanges show that the presence of black immigrants in the Territory was intended to remain an exceptional situation, which had to be strictly controlled and limited. The immigration policy vis-à-vis Afro-Belizean forestry workers is another example. Officially, they were banned under the immigration laws, but it became necessary to allow them in 
because of the near-total absence of a local population and the need for a workforce to develop forestry.

In 1925, Quintana Roo's immigration officer was worried about the problems caused by "letting in a growing number of BLACKS ${ }^{19} \ldots$ adding further to those already in the Territory and all those who immigrate illegally through parts of the border that are not under control." ${ }^{20}$ After looking into the situation, the Immigration Department in Mexico City said, "it was absolutely opposed to letting in individuals of inferior races," in a decision justified in the four points below:

In recent years, the government has positioned itself against the immigration of the ETHIOPIAN and MONGOL races that, for well-known ethnological reasons, are a threat to our embryonic nationality.

The profusion of BLACKS in the Quintana Roo Territory has transformed it into a kind of Colonial State, thus delaying its progress and its true and absolute identification with the rest of the Homeland.

Lumber companies and those extracting chicle seek BLACK workers for unjust reasons from a moral and legal point of view: they employ them in conditions of slavery and give them very harsh and incredibly lengthy tasks at tiny salaries, all these being accepted in an illicit contract that provides assured profits to the owners.

Conversely, inside the country, idle workers are struggling to emigrate to the United States. $^{21}$

The ban on black workers was justified by numerous arguments: a pseudoscientific argument that placed the ban within the framework of the construction of national identity; the threat that Quintana Roo would be colonized by the British; a denunciation of slavery practiced by foreign forestry companies; and competition with Mexican workers forced to emigrate to the United States.

Yet, at the beginning of the following year (January 2, 1926), Payo Obispo's immigration officer adopted a different line. He sent a letter to the Immigration Department in Mexico City, "Report on the Immigration of the Black Race." He deemed the immigration of black workers "indispensable," and directly related to the "Federation's interests" (in other words, the tax revenue derived from the extraction and export of forest products). Black workers were not used as substitutes for Mexican workers who refused to go to the Territory, even when they did not have a job in their region of origin. The immigration officer backed up his stance with opinions from the highest local authorities: the governor, the head of military operations, and the commander of the Flotilla y los Servicios Navales (Navy): all requested exceptional treatment for Quintana Roo. For the 
governor, "in this Territory, because of its particular situation, it is not possible to apply a number of regulations drawn up for the country as a whole. Should the immigration of blacks be banned, forestry would have to be stopped because nobody would be able to replace them."22

The immigration officer also stated that this immigration would have to be carried out under specific conditions: "The risk that they mix their race with ours" 23 was to be defused by stationing the Belizean workers in faraway forest camps. The head of the Immigration Department gave in: on March 1, 1926, he authorized the immigration of black workers to the Quintana Roo Territory, although he also emphasized that such measures were granted as an exception because of aspects specific to that region; in fact, he stated, the case of Belizean workers could not be regarded as "real immigration" and as such did not call into question the national legal framework. The Afro-Belizean workers' stay was to be subjected to numerous conditions: the number of black workers and their length of stay was set, their place of work was predetermined, they had to obtain a passport for stays exceeding six months, and each had to be examined by representatives of the Health Department. They also had to obtain work contracts from the companies employing them, and a guarantee had to be deposited with Payo Obispo's customs authorities, and entries and exits duly registered.

This type of discussion on the immigration of black workers persisted until the beginning of the 1940s. It suggests that black people were characterized as "undesirables" in order to enforce national migratory legislation. The Quintana Roo Territory's particular context (sparsely populated, with vast forest expanses, and bordering British Honduras) also led to further stigmatizing of black immigrants, who were considered to be illegal, albeit economically necessary aliens. They were accepted into the country out of economic necessity, but confined to a status of radical otherness and controlled in order to make sure that they would not be integrated, as part of the mestizaje process, into the nation.

\section{Foreigners and Access to Land: From Being Banned to Becoming Invisible}

The issue of access to land offers a good example of how foreigners were viewed: There was an official prohibition against land ownership by black foreigners at the same time that, locally, the law was observed in the breach. I analyze below how "black foreigners" no longer were viewed as a "problem" for the authorities as long as they remained in the country.

Most of the land allocation in ejidos in the south of the Territory took place between 1935 and 1941 (with another wave from 1960 to 1970, when the State was being created). In the south of the Territory, this resulted in a concentration of the population along the Río Hondo border because the ejidos were located by the 
river. The government contributed to the development of infrastructure (drinking water, health centers, and schools, for example). At the same time, production and consumer cooperatives were created; they were aimed at chicle and forestry activities. Access to both ejidos and cooperatives was reserved for national citizens.

Article 27 of the 1917 Constitution restricts the acquisition of land to Mexican citizens. Consequently, the 1934 land code (article 44) states that only Mexican citizens are entitled to a parcel of farmland in an ejido (Departamento Agrario 1934:36). Furthermore, article 57 of the Ley general de sociedades cooperativas (General Cooperative Law) stipulates that production cooperatives "cannot accept more than 10 percent of foreigners among their members" (Diario oficial, February 15, 1938, No. 17).

Thus, only Mexican citizens are listed as members of the cooperatives established along the Río Hondo, with a few exceptions. The Federación de trabajadores de Quintana Roo (Workers' Federation of Quintana Roo) states in its program of action that employers must hire Mexican workers: it invites workers from the rest of the Republic, and "persons born in a foreign land but from Mexican parents, to colonize the Territory ("Programa mínimo de acción," Periódico oficial del Territorio de Quintana Roo, July 1, 1936, tomo I, No. 10). The creation of cooperatives and introduction of the ejido system resulted in the arrival of Mexicans to colonize the region and ousting of foreigners who lived there: "Nomadic workers who were based in Chetumal (or elsewhere in the country) and went into the jungle for lengthy periods (several months) were replaced by stable human groups with a family structure, that were based in the ejido's urban nucleus and went into the jungle for short periods (a few weeks)" (Galletti 1993: 155).

Several reports by Andrés R. Barajas, who was the Secretaría de Gobernación's representative to the Chiclero Committee at the end of $1936,{ }^{24}$ offer a better understanding of the relationships among immigration policies, colonization policies, and the ejidos/cooperatives. The August, September, and October reports concern the establishment of cooperatives in the Territory. The first report, regarding "activities developed by the Organization Committee of Cooperative Companies and Immigration Issues," establishes a direct connection between cooperatives and immigration. In fact, Barajas came up against a recurring problem, which he describes as "conditions of foreignness" — that is, the large number of foreigners in Chetumal and along the Río Hondo. Black immigration was illegal but tolerated in Quintana Roo because of the Territory's particular demographic and economic situation. Moreover, many workers did not register and escaped controls by immigration officers. Andrés Barajas observed that "every year, black workers are being introduced surreptitiously for felling trees without our Immigration Department being able to avoid this." 25 According to Andrés Barajas, the situation would only be resolved by the workers themselves, organized in cooperatives. "From this year onward the problem will be eliminated because the activity will be run by those 
concerned, namely the members of cooperatives, and they'll make sure not to allow them [the black foreigners] in because that would go directly against their own interests." ${ }^{" 26}$ Foreigners, in particular Afro-Belizeans, were not seen as compatible with the new way in which forestry activities were being organized. The new ejidos and cooperative members thus become the best guarantors of the eviction of concession holders, control of the activity, and fight against the immigration of Afro-Belizean workers.

However, as was the case with the immigration laws, a study of how these measures concerning land and agriculture were applied reveals flaws and gaps in administrative practices that made it possible for a number of foreigners to settle in the Quintana Roo Territory. Examining the general agricultural and fishing censuses (Censos generales y agropecuarios) carried out prior to creating the ejidos, and lists of beneficiaries of ejidos when parcels of land were allocated, reveals that black foreigners had disappeared from administrative categories, but not as social actors.

On a number of census forms, the column "nationality" is not filled in (such is the case with the Pucté, Botes, and Sabidos ejidos, for instance). On others, the nationality indicated is systematically noted as "Mexican" (in Palmar and Cocoyol), but additional notes in the "observation" column show that numerous individuals were born in Belize. The parents' origin is mentioned in several cases: both parents born in Belize, father born in Mexico and mother in Belize, and parents of unknown nationality. Overall, people born in Belize, from Belizean parents, or whose nationality could not be proven, appear in censuses as Mexican. In other cases, some foreigners did have access to land. Such was the case with Enrique Padilla, a 35-year-old mulatto, who had been living in Alvaro Obregón ${ }^{27}$ for two years; he came from Honduras, and was a farmer and a chiclero. In the 1941 census, his house was registered but he was not entitled to a parcel of land in an ejido; however, his name appears in the final list of the ejido's signatories, which was drawn up in $1942 .^{28}$

Indications about race are also found in some censuses. The Alvaro Obregón ${ }^{29}$ census, published on June 7, 1941, lists, for example, 173 individuals, including 137 Mayas, 9 Huastecos, 2 mestizos, and 1 Tarahumara. It also mentions seven blacks and five mulattos. One of them is Panfilo Castellanos, black, aged 32, residing in the village for 23 years, born in Guatemala, farmer and chiclero. He is married to Maria Santos Cárdenas, black, aged 25, a resident for 18 years, born in Belize. They have four children aged 9, 7, 2, and 1, also identified as black, and they live with Nicolasa Castellanos, black, aged 50, born in Guatemala. Panfilo Castellanos is not entitled to a parcel of an ejido; nevertheless, he owns a house. Panfilo Castellanos's case (and similar cases exist in a number of villages along the Río Hondo-Ramonal, Botes, and Sabidos, for example) shows that foreign black families settled in the region on a long-term basis, slipping through immigration 
and land laws. On the other hand, the presence of black or mulatto women born in Belize or elsewhere in Central America indicates the permanence of an Afrodescendent population of foreign origin. Thus, for example, Isabel Morales, aged 27, mulatto, born in Honduras, has been living in Alvaro Obregón for a year. She is married to Tomas Benito from Tuxpan (Mexico) who obtains permanent right to a parcel of an ejido; Horalia Perdomo, aged 25, mulatto, born in Belize and residing in Alvaro Obregón for ten years, is married to Mariano Varela, from Puebla (Mexico), who obtains a parcel of land as part of an ejido. Also interesting to note is the racial classification of children from mixed families: for example, the children, classified as Mayas, of Julio Betancourt, mulatto, residing in Alvaro Obregón for seven years, farmer and chiclero, and of Francisca García, Maya. This identification indicates a trend toward dropping the black category, which does not mean that there were no longer any descendants of Africans.

In the end, land authorities, even though they were not acting along racial lines, contributed knowingly to erasing from the administrative documents the presence of foreign black people. Moreover, in certain cases, failure to enforce the law led to a disappearance of racial and national descriptions for some people, and consequently they were able to remain in Mexico. Prohibiting access to land to black foreigners and suppressing the black foreigner "problem" in administrative categories were not acts that were synonymous with the "disappearance" of black populations.

\section{Nationalism on the Border: Becoming Mexican ... and Mestizo}

The Quintana Roo Territory was integrated into the nation under President Lázaro Cárdenas (between December 1934 and November 1940). ${ }^{30}$ Rafael Melgar, leader of the Campaña Nacionalista (Nationalist Campaign) at the beginning of the 1930s, aimed to rally all sectors of society in order to modernize the country. He was appointed governor of the Territory and put postrevolution nationalism into practice by developing means of communication, improving infrastructure, creating cooperatives, and attracting Mexican settlers. The Campaña Nacionalista also initiated a kind of popular patriotism via the celebration of historic events and cultural features, and by granting rights (e.g., to education or health). This policy, at times criticized for its xenophobic excesses, emphasized training programs aimed at helping foreigners to assimilate culturally (Loyo 1935: 27). In this context, black foreigners in Quintana Roo were encouraged to become "mexicanized" by adhering to cultural patriotism and accessing the consumer society, and health and education services. Mexican nationalism's capacity to absorb otherness resulted in the reference to race or "black" color becoming insignificant. Black immigrants became "like" Mexicans and hence, "like" mestizos, since Mexican and mestizo categories were synonymous in Mexican postrevolutionary nationalist discourses. 
This was the case even though they also had physical characteristics identified as black, or a personal history related to postslavery migrations.

Governor Rafael Melgar advocated for nationalizing and mexicanizing the Quintana Roo region, which was regarded as still "wild." "Socialist Saturdays" and civic education programs were introduced with the aim of "improving the culture" of the region's inhabitants. The first accounts of local history appeared, the most striking being those of Luis Rosado Vega (1940) and Gabriel Menéndez (1936). Also at this time, a number of place names were "mexicanized": for example, Payo Obispo became Chetumal, Santa Cruz Chico became Pedro A. Santos, Campamento Mengel became Alvaro Obregón, and Bahía de la Ascensión became Bahía Emiliano Zapata. A physical education department was created to "make our race sturdier," while an information service reported national news, thus contributing to the insertion of the Territory into the life of the country.

The Periódico oficial del Territorio de Quintana Roo ${ }^{31}$ (The Official Gazette of the Quintana Roo Territory) was first published in 1936; it is a useful document in this context, and discusses matters taking place in Chetumal and more generally in the south of Quintana Roo. It outlines the construction of urban infrastructure: a power plant in Chetumal, water tanks in villages, the Belisario Domínguez school, and several hospitals; it also notes modes of payment of taxes, health regulations, the launching of socialist education programs, literacy and antialcoholism campaigns, actions to improve workers' rights, the creation of a 'best rural school' contest. The Periódico oficial also exemplifies the nationalism of the period: thus, on September 1, 1937, it published a message from President Cárdenas: "This is how you build a nation!" (tome II, No. 38), and on October 15, 1939, it set the dates of patriotic days (the anniversary of the Constitution, independence, the battle of May 5, for example) while reminding people that celebrating these days was particularly important in this border region (tome IV, No. 19).

The newspaper En Marcha ${ }^{32}$ was the mouthpiece of the Federation of Cooperatives; the Federation was often praised in its pages, notably by stressing what the conditions of Quintana Roo were like "before" the Melgar governmentunhygienic, impoverished, dangerous — whereas afterwards, they were viewed as progressive, healthy, and democratic. The newspaper was run by Gustavo Durán Vilchis, who was also Secretary General of the Quintana Roo government, thus providing further evidence of its role in disseminating the regime's official policy. It regularly published calls to "be patriotic." Cultural brigades were sent throughout the Territory, literacy campaigns were launched, and teachers became the heralds of a kind of popular patriotism. A Chetumal patriotic assembly (Junta patriótica) and the title of Miss Liberty (Señorita libertad) were created; national celebrations were given a prominent place (anniversaries of independence, and revolution, "Mother's Day," Day of the Race). A "monument to the flag" appeared at the center of Chetumal on the esplanade bearing the same name. The cooperative 
system was regularly praised for having brought economic prosperity to the Territory and new status for workers, including remuneration, access to health and education, work, and freedom.

Eventually, Quintana Roo became Mexican, and its Mexican nature was defined in terms of access to rights, a patriotic education, and popular nationalism. The racial question had been resolved, since "Mexicans" could only be mestizos. This policy, whereby access to rights depended upon inclusion in a Mexican national identity, was neither limited to the Quintana Roo Territory nor specifically aimed at black populations. ${ }^{33}$ It lay within the framework of Mexican postrevolution nationalism and indigenist ideology, which became institutionalized during the 1940s (in the Pátzcuaro congress in 1940, and in the Instituto Nacional Indigenista in 1948).

\section{Conclusion}

The elimination of the "black question" was achieved primarily through changes in the composition of the population as a result of immigration and land policies, and by the ways in which these were adapted by local authorities. Black people were reduced to the status of illegal immigrants or foreigners under control. The former symbolized the prerevolution exploitation of workers and the existence of a prerevolution uncivilized region not integrated into the nation. Luis Rosado Vega, the Territory's official historian under the Cárdenas government, conveys an image of a cruel, inhuman, and hostile nature: "The insatiable and voracious jungle, the huge forest of the Quintana Roo Territory, so extensive that it covers everything, a wild and frantic jungle, a craze of trees feverish with overflowing sap, a craze of exuberant vegetation." He also evoked "its semi-African jungles and rivers" (Rosado Vega 1938: 220). The black man was associated with the status of chiclero, exploited by foreign companies that had to disappear in the postrevolution society.

However, the solution to the "black problem" was also a result of the Mexican state's drive toward homogenization. People became entitled to Mexican rights, and hence mestizo — race became defined by citizenship—even though one might also be black. This characteristic dissolved with citizenship and mestizaje, to become, if not insignificant, at least of secondary importance.

After the end of the Second World War, the production of chicle dropped considerably (it was replaced by synthetic chewing gum) and the government favored the cultivation of sugarcane. The authorities wanted to grant the Quintana Roo Territory the status of State within the Federation. To attain this objective, it was necessary to boost the economy (with two major projects: sugar plant in the South of the Territory and touristic development of Cancún in the North). It was necessary to reinforce infrastructure (roads), modernize the administration, and increase the population (with an internal colonization policy) in order to ensure 
the new state's political, economic, and demographic viability and to guarantee its material and symbolic integration into the nation. When in 1974 the Territory became the State of Quintana Roo, the Afro-Belizean migrations-which had occurred at the beginning of the 20th century - were no longer part of the regional history, which was in the process of being written (Álvarez Coral 1971; Hoy 1983). Thus, "black" was transformed into an exogenous otherness, in racial and national terms, and into a nonproblematic and nonsalient "sameness": the black person was, alternatively, "the other" or "the same." In either case, the conclusion was identical: the term "black Mexican" appeared to be an oxymoron, either because "blacks" disappeared from national identity as foreigners, or because they became citizens, and hence mestizos. In a contradictory way, mestizaje is both a political logic of exclusion of the black foreigner, as well as an integration of racial differences.

\section{Notes}

${ }^{1}$ See Chomsky (1996); for a broad overview, see also Harpelle (2000) on Costa Rica, Chambers (2010) on Honduras, O’Reggio (2006) on Panama, Opie (2009) on Guatemala, and Putnam (2010, 2013).

${ }^{2}$ Latex, from which chewing gum is made.

${ }^{3}$ Other archives were consulted but were not directly used in this article: The National General Archives (Archivo General de la Nación) in México City, Diplomatic Historical Archives of the Ministry of Foreign Affairs (Archivo Histórico Diplomático de la Secretaría de Relaciones Exteriores) in México City, and Belize Archives in Belmopan.

${ }^{4}$ The ejido is a form of collective land ownership that became one of the main instruments of the land reform initiated during the 1910 Revolution; it was formalized in the 1917 Constitution.

${ }^{5}$ The terms "black," "Afromestizo," and "Afro-Mexican" refer to logics of classification combining racial, ethnic, and national dimensions, respectively. Their meaning is contextual.

${ }^{6}$ Several contemporary studies on Afro-descendant people in Mexico examine Gonzalo Aguirre Beltrán's conclusions and discuss a "third root" of mestizaje; they analyze the emergence of political mobilization, question the permanence of a racist ideology, and discuss logics of inclusion and exclusion of the black population (Hoffmann 2006).

${ }^{7}$ Available at the Centro de Estudios de la Historia de México (reference 041 V. A. 1910).

${ }^{8}$ Alberto M. Carreño, "El peligro negro.”

${ }^{9}$ Alberto M. Carreño, "El peligro negro."

${ }^{10}$ Alberto M. Carreño, "El peligro negro."

${ }^{11}$ Alberto M. Carreño, "El peligro negro.”

${ }^{12}$ See Ota Mishima (1997), Palma Mora (2006), Rodríguez Chávez (2010), and Gleizer (2011).

${ }^{13}$ Until 1937, Payo Obispo was the name given to Chetumal, Quintana Roo's current capital, located on the border with Belize. In what follows, I use Payo Obispo and Chetumal as they appear in the documents consulted.

${ }^{14}$ Archivo Histórico del Instituto Nacional de Migración, 4-351-1-1925-8, Telegrama del agente encargado de migración, Payo Obispo, October 18, 1925, al subsecretario de gobierno, Departamento de migración. As Belize was a British colony, its inhabitants were classified as English.

${ }^{15}$ Archivo Histórico del Instituto Nacional de Migración, 4-100-07-1926-66, Carta del Capitan del barco, El agente sanitario (Pedro J. Cervera) al Agente de Migración (Francisco S. Valencia), Payo Obispo, August 3, 1926. 
${ }^{16}$ Archivo Histórico del Instituto Nacional de Migración, 4-360-1926-857, del Agente de migración al Secretario de gobernación, Payo Obispo, August 11, 1926.

${ }^{17}$ Archivo Histórico del Instituto Nacional de Migración, 4-362-1-1929-306, Telegrama de Delegado de migración al Subsecretario de Gobierno, Departamento de migración, June 12, 1929; Telégrafo del director de educación federal al Secretario de gobierno, Payo Obispo, June 13, 1929; Telegrama del Subsecretario de Gobierno al Secretario de gobernación, Payo Obispo, July 9, 1929.

${ }^{18}$ Archivo Histórico del Instituto Nacional de Migración, 4-362-1-1929-306, Telegrama de Delegado de migración al Subsecretario de Gobierno, Departamento de migración, June 12, 1929; Telégrafo del director de educación federal al Secretario de gobierno, Payo Obispo, June 13, 1929; Telegrama del Subsecretario de Gobierno al Secretario de gobernación, Payo Obispo, July 9, 1929.

${ }^{19}$ All capitalized references are in original.

${ }^{20}$ Archivo Histórico del Instituto Nacional de Migración, 4-350-1925-32, Aviso del Departamento de Migración, December 1925.

${ }^{21}$ Archivo Histórico del Instituto Nacional de Migración, 4-350-1925-32, Aviso del Departamento de Migración, December 1925.

${ }^{22}$ Archivo Histórico del Instituto Nacional de Migración, 4-350-1925-32, carta del Agente encargado del Servicio general de migración, Payo Obispo, January 2, 1926, al Secretario de Gobernación, Departamento de migración, México DF.

${ }^{23}$ Archivo Histórico del Instituto Nacional de Migración, 4-350-1925-32, carta del Agente encargado del Servicio general de migración, Payo Obispo, January 2, 1926, al Secretario de Gobernación, Departamento de migración, México DF.

${ }^{24}$ Archivo Histórico del Instituto Nacional de Migración, 4-100-07-1926-66, Informe de Andrés R. Barajas, representante de la Secretaría de Gobernación ante el Comité chiclero, al Secretario de Gobernación, Departamento Administrativo, México DF, October 2, 1936.

${ }^{25}$ Archivo Histórico del Instituto Nacional de Migración, 4-100-07-1926-66, Informe de Andrés R. Barajas, representante de la Secretaría de Gobernación ante el Comité chiclero, al Secretario de Gobernación, Departamento Administrativo, México DF, October 2, 1936.

${ }^{26}$ Archivo Histórico del Instituto Nacional de Migración, 4-100-07-1926-66, Informe de Andrés R. Barajas, representante de la Secretaría de Gobernación ante el Comité chiclero, al Secretario de Gobernación, Departamento Administrativo, México DF, October 2, 1936.

${ }^{27}$ The case of Alvaro Obregón is particularly interesting because the village is located on the site of the former Campamento Mengel, which was probably the biggest forestry camp at the beginning of the century (it had several hundred workers and a railway line, for example).

${ }^{28}$ Archivo General Agrario, dotación de ejidos, Alvaro Obregón, Exp. 24227, Acta de deslinde y posesión definitiva, December 12, 1942.

${ }^{29}$ Archivo General Agrario, dotación de ejidos, Alvaro Obregón, Exp. 24227, Acta de junta censal, June 7, 1941, censo de 7 fojas. Censo general y agropecuario de Alvaro Obregón.

${ }^{30}$ Claimed by the neighboring States of Campeche and Yucatán, the Quintana Roo Territory was abolished twice, from 1913 to 1915, and then again, from 1931 to 1935.

${ }^{31}$ Archivo Histórico del Estado de Quintana Roo, sección hemeroteca.

${ }^{32}$ Archivo Histórico del Estado de Quintana Roo, sección hemeroteca.

${ }^{33}$ See the analysis of Mexican indigenism or Nolan-Ferrell (2012), on the case of Guatemalans in Chiapas.

\section{References Cited}

Adelman, Jeremy, and Stephen Aron. 1999. "From Borderlands to Borders: Empires, Nation-states, and the Peoples in Between in North American History.” American Historical Review 104(3): 814-41. 
Aguirre Beltrán, Gonzalo. 1974 [1958]. Cuijla, esbozo etnográfico de un pueblo negro. México: Fondo de Cultura Económica.

Aguirre Beltrán, Gonzalo. 1989 [1946]. La población negra de México. Estudio etnohistórico México: Universidad Veracruzana, Instituto Nacional Indigenista, Gobierno del Estado de Veracruz, Fondo de Cultura Económica.

Álvarez Coral, Juan. 1971. Historia de Quintana Roo. Chetumal: Edición del Gobierno de Quintana Roo, México, Taller de B. Costa-Amic.

Basave Benítez, Agustín F. 2002. México mestizo: análisis del nacionalismo mexicano en torno a la mestizofilia de Andrés Molina Enríquez, 2nd edition. México: Fondo de Cultura Económica.

Brown, Jonathan C. 1993. "Foreign and Native-Born Workers in Porfirian Mexico." American Historical Review 98: 786-818.

Cal Angel, Eduardo. 1983. Anglo Maya Contact in Northern Belize: A Study of British Policy Toward the Maya During the Caste War of Yucatán, 1847-1872. Calgary, Alberta: Department of History.

Chambers, Glenn. 2010. Race, Nation, and West Indian Immigration to Honduras, 1890-1940. Baton Rouge, LA: Louisiana State University Press.

Chomsky, Aviva. 1996. West Indian Workers and the United Fruit Company in Costa Rica, 1870-1940. Baton Rouge, LA: Louisiana State University Press.

Cook-Martín, David and David FitzGerald. 2010. "Liberalism and the Limits of Inclusion: Race and Immigration Law in the Americas, 1850-2000.” Journal of Interdisciplinary History 41: 7-25.

Cunin, Elisabeth. 2014. Administrer les étrangers au Mexique. Migrations afrobéliziennes dans le Quintana Roo, 19021940. Paris: Karthala Collection Esclavage, IRD.

Departamento Agrario. 1934. Código agrario de los Estados Unidos Mexicanos. México: TIP La Impresora.

Galletti, Hugo Alfredo. 1993. "Actividades forestales y su desarrollo histórico." In Estudio integral de la frontera México-Belice. Análisis socioeconómico, edited by Alfredo A. César Dachary, 131-98. Chetumal: Centro de Investigaciones de Quintana Roo.

Gamio, Manuel. 1982 [1916]. Forjando patria, $3^{a}$ edición. México: Editorial Porrúa SA.

Gerhard, Peter. 1991. La frontera sureste de la Nueva España. México: Ed. UNAM.

Gleizer, Daniela. 2011. El exilio incómodo. México y los refugiados judíos, 1933-1945. México: El Colegio de México, UAM-Cuajimalpa.

González Navarro, Moisés. 1960. La colonización en México. 1877-1910. México: Talleres de impresión de estampillas y valores.

González Navarro, Moisés. 1988. “Las ideas raciales de los científicos, 1890-1910.” Historia Mexicana 37: 565-84.

Harpelle, Ronald N. 2000. "Racism and Nationalism in the Creation of Costa Rica's Pacific Coast Banana Enclave." The Americas 56: 29-51.

Hoffmann, Odile. 2006. “Negros y afromestizos en México: viejas y nuevas lecturas de un mundo olvidado." Revista Mexicana de Sociología 68: 103-35.

Hoy, Carlos. 1983. Breve historia de Quintana Roo. Chetumal: Gobierno del Estado de Quintana Roo.

Jones, Grant D. 1971. "La estructura política de los mayas de Chan Santa Cruz: El papel del respaldo inglés." América Indígena 31: 415-28.

Knight, Alan. 1990. "Racism, Revolution and Indigenismo: Mexico, 1910-1940." In The Idea of Race in Latin America, 1870-1940, edited by Richard Graham, 71-113. Austin, TX: University of Texas Press.

Loyo, Gilberto. 1935. La política demográfica de México. México: PNR, Talleres Tipográficos de S. Turanzas del Valle.

Menéndez, Gabriel Antonio. 1936. Quintana Roo. Album monográfico. México: Edición facsimilar. Talleres de Multicolor. S. A. de C. V. México.

Nolan-Ferrell, Catherine. 2012. Constructing Citizenship: Transnational Workers and Revolution on the MexicoGuatemala Border, 1880-1950. Tucson, AZ: University of Arizona Press.

Opie, Frederick Douglass. 2009. Black Labor Migration in Caribbean Guatemala, 1882-1923. Miami, FL: University of Florida.

O'Reggio, Trevor. 2006. Between Alienation and Citizenship: The Evolution of Black West Indian Society in Panama, 1914-1964. Lanham, MD: University Press of America.

Ota Mishima, María Elena (coord.). 2006. Destino México. Un estudio de las migraciones asiáticas a México, siglos XIX y XX. México: El Colegio de México, Centro de Estudios de Asia y África, 1997.

Palma Mora, Mónica. 2006. De tierras extrañas. Un estudio sobre la inmigración en México, 1950-1990. México: Segob-AHINM-Centro de Estudios Migratorios, INAH, DGE Ediciones.

Putnam, Lara. 2010. "Eventually Alien: The Multigenerational Saga of British Western Indians in Central America, 1870-1940.” In Blacks and Blackness in Central America: Between Race and Place, edited by Lowell Gudmundson and Justin Wolfe, 278-306. Durham, NC: Duke University Press.

Putnam, Lara. 2013. Radical Moves: Caribbean Migrants and the Politics of Race in the Jazz Age. Chapel Hill, NC: University of North Carolina Press. 
Restall, Matthew. 2014. "Crossing to Safety? Frontier Flight in Eighteenth-Century Belize and Yucatan.” Hispanic American Historical Review 94: 381-419.

Rippy, J. Fred. 1921. “A Negro Colonization Project in Mexico, 1895.” The Journal of Negro History 6: 66-73.

Rodríguez Chávez, Ernesto, editor. 2010. Extranjeros en México. Continuidades y aproximaciones. México: Centro de Estudios Migratorios, AHINM, DGE Ediciones.

Rosado Vega, Luis. 1938. Claudio Martín. Vida de un chiclero. México DF: Ediciones SCOP.

Rosado Vega, Luis. 1940. Un pueblo y un hombre. Chetumal: Editorial Norte Sur.

Saade Granados, Marta. 2009a. El mestizo no es “de color." Ciencia y Política Pública Mestizófilas (México, 1920-1940). México: ENAH, Tesis de doctorado en historia.

Saade Granados, Marta. 2009b. "Una raza prohibida: afroestadounidenses en México.” In Nación y extranjería. La exclusión racial en las políticas migratorias de Argentina, Brasil, Cuba y México, edited by Pablo Yankelevitch, 231-76. México: UNAM, Programa México Nación Multicultural.

Scott FitzGerald, David and David Cook-Martin. 2014. Culling the Masses. The Democratic Origins of Racist Immigration Policy in the Americas. Cambridge: Harvard University Press.

Serna, Juan Manuel de la. 2011. "Los afro-norteamericanos y la formación de la nacionalidad mexicana en el siglo XIX.” REDE-A 1: 108-21.

Villalobos González, Martha Herminia. 2006. El bosque sitiado. Asaltos armados, concesiones forestales y estrategias de resistencia durante la Guerra de Castas. México: INAH-CIESAS-Miguel Ángel Porrúa, Colección Peninsular.

Vincent, Ted. 1997. "Black Hopes in Baja California: Black American and Mexican Cooperation, 1917-1926." The Western Journal of Black Studies 21: 204-13.

Yankelevich, Pablo, editor. 2009. Nación y extranjería. La exclusión racial en las políticas migratorias de Argentina, Brasil, Cuba y México. México: UNAM, Programa México Nación Multicultural.

Yankelevich, Pablo. 2011. Deseables o Inconvenientes? Las fronteras de la extranjería en el México posrevolucionario. México: Bonilla Artigas Eds, ENAH, Iberoamericana Vervuert. 